\title{
Penerapan Business Model Canvas pada E-Commerce Toko H5 Jayapura
}

${ }^{1}$ Azwar Annas, ${ }^{2}$ Muhammad Taher Jufri, ${ }^{3}$ Jusmawati

1,2,3 Universitas Yapis Papua, Indonesia

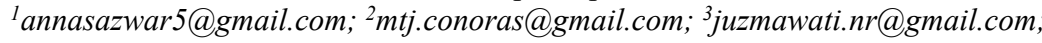

\begin{tabular}{l}
\hline Article Info \\
\hline Article history: \\
Received, 14-06-2021 \\
Revised, 18-06-2021 \\
Accepted, 25-06-2021 \\
\hline Kata Kunci: \\
e-commerce \\
business model canvas \\
toko h5 \\
bisnis \\
fashion \\
\hline \hline
\end{tabular}

Keywords:

e-commerce

business model canvas

toko h5

business

fashion

\begin{abstract}
ABSTRAK
Toko H5 merupakan toko yang bergerak dibidang fashion. Sistem pada Toko H5 yang secara keseluruhan masih konvensional menjadi permasalahan pertama yang ditemukan. Masalah lain datang selama masa pandemi, omset yang menurun cukup signifikan diperikarakan mencapai 50\% dibanding sebelum masa pandemi. Business Model Canvas (BMC) adalah suatu model strategi bisnis yang menggunakan sembilan blok penting. BMC digunakan oleh perusahaan dan startup untuk mendapatkan wawasan tentang analisis model bisnis mereka. Penelitian ini menyelesaikan permasalahan dengan analisis proses bisnis yang dilakukan dengan metode BMC untuk memberikan hasil penelitian berupa $e$-commerce sehingga model bisnis yang ada kemudian dapat diubah menjadi model bisnis berbasis e-commerce di web. Tujuannya yakni dengan adanya sistem ini dapat mengoptimalkan kinerja terutama peningkatan sektor penjualan produk sehingga dapat meningkatkan omset pada Toko H5, karyawan menjadi mudah melakukan pendataan stok dan laporan penjualan yang dilakukan menggunakan sistem, serta membantu pelanggan untuk berbelanja secara online melalui E-Commerce.
\end{abstract}

\section{ABSTRACT}

H5 store is a store engaged in fashion. The system in H5 store which is still conventional as a whole became the first problem found. Another problem came during the pandemic, turnover decreased significantly by $50 \%$ compared to before the pandemic. Business Model Canvas (BMC) is a business strategy model that uses nine important blocks. BMC is used by companies and startups to gain insights into the analysis of their business models. This research solves the problem with business process analysis conducted by BMC method to provide research results in the form of e-commerce so that existing business models can then be converted into e-commerce-based business models on the web. The goal is that with this system can optimize performance, especially the increase in the product sales sector so as to increase turnover in H5 Stores, employees become easy to do stock collection and sales reports conducted using the system, as well as help customers to shop online through ECommerce.

This is an open access article under the CC BY-SAlicense.

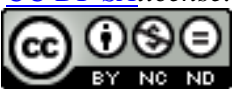

\section{Penulis Korespondensi:}

Email:

\section{PENDAHULUAN}

Kemajuan di bidang bisnis saat ini e-commerce menjadi faktor yang meningkatkan dan memenangkan persaingan komersial dan penjualan produk. E-commerce adalah bentuk transaksi yang terkait erat dengan aktivitas komersial skala individu dan sistem berdasarkan pemrosesan dan transmisi data digital seperti teks, audio, dan gambar. Tolok ukur yang umum digunakan dalam e-commerce yakni aplikasi bisnis yang menggunakan media internet untuk melakukan transaksi online dalam pembelian produk atau jasa [1].

Dalam mengembangkan sebuah bisnis perlu dilakukannya analisa secara mendalam tentang kekuatan dan kekurangan bisnis yang akan dilakukan. Business Model Canvas (BMC) merupakan metodologi yang menyajikan sembilan blok utama untuk memberikan gambaran tentang strategi bisnis yang akan diterapkan. Pengembangan BMC digunakan untuk membantu pemilik dan pengusaha baru serta organisasi bisnis dalam memetakan dan menganalisis model bisnis yang akan diterapkan [2]. 
Toko H5 adalah sebuah Toko yang bergerak dibidang fashion. Produk-produk yang dijual berupa baju, celana, jaket, dress mulai dari anak-anak hingga dewasa dengan bekerja sama dengan supplier-supplier yang terpilih. Toko H5 mempunyai beberapa masalah baik yang terjadi sebelum pandemi, ataupun pada masa pandemi itu sendiri. Masalah yang ditemukan sebelum masa pandemi yakni sistem pada Toko H5 yang secara keseluruhan masih konvensional, seperti pendataan stok dan laporan penjualan oleh karyawan yang masih dilakukan secara manual pada buku, laporan penjualan memilik fungsi sebagai salah satu acuan dasar yang dimiliki oleh Toko H5 untuk berbelanja kebutuhan produk dikemudian hari, hal ini sangat beresiko terjadinya kehilangan atau kerusakan data terkait penjualan tersebut ketika sistem yang diterapkan pada Toko H5 masih konvensional.

Masalah lain datang pada masa pandemi, omset yang menurun cukup signifikan diperikarakan mencapai $50 \%$ jika dibandingkan dengan sebelum masa pandemi. Penurunan ini berkaitan dengan anjuran untuk berada di rumah saja yang ditetapkan oleh pemerintah serta mematuhi protokol kesehatan yang ada, selain itu diberlakukannya pembatasan jam malam di masa pandemi hingga pukul 21.00 WIT tentunya mempengaruhi proses jual beli yang terjadi pada Toko H5. Pelanggan yang sebelumnya datang langsung ke toko sekarang beralih mencari alternatif lain yaitu dengan berbelanja secara online di marketplace ternama seperti Tokopedia, Shopee, dan lainnya.

Solusi yang dapat diberikan berdasarkan masalah yang ada berupa penerapan sebuah E-Commerce menggunakan pemodelan bisnis BMC untuk menganalisis proses bisnis yang sedang berlangsung dan bertujuan untuk mengubah model bisnis yang ada menjadi model bisnis E-Commerce berbasis situs web.. Tujuannya agar menghasilkan kinerja yang lebih optimal, E-Commerce yang ada nantinya dapat membantu Toko fisik yang tetap buka, yang menjadi pertimbangan yakni pelanggan dapat berbelanja secara langsung pada Toko fisik maupun melalui E-Commerce yang ada untuk mendapatkan kemudahan, sehingga Toko H5 mengalami peningkatan penjualan produk yang dapat meningkatkan omset pada Toko H5 itu sendiri, dan adanya E-Commerce juga memudahkan karyawan dalam melakukan pendataan stok dan laporan penjualan. Penelitian ini bertujuan yaitu sebagai berikut:

1. Membantu meningkatkan omset pada Toko H5 Jayapura.

2. Memudahkan pemilik toko mengelola Toko H5 berdasarkan laporan yang ada sebagai dasar pengambilan keputusan kedepannya.

3. Memudahkan dan mengoptimalkan kerja dari karyawan dalam melakukan pendataan dan ketersediaan stok barang, serta laporan penjualan.

4. Memudahkan pelanggan untuk berbelanja pada Toko H5 melalui E-commerce.

Beberapa penelitian terdahulu mempunyai pandangan berbeda dalam penelitiannya dan peneliti akan mengangkat beberapa penelitian tersebut sebagai referensi dalam menambah bahan kajian, yaitu:

1. Penelitian yang dilakukan oleh Setiani dan Wibowo menghasilkan Website E-commerce yang dapat menyajikan beberapa laporan yang akan ditujukan kepada pemilik toko sebagai pertimbangan dalam hal perbaikan pelayanannya dan juga pengambilan keputusan [3].

2. Penelitian yang dilakukan oleh Widiani, Pudjiantoro, dan Hadian menghasilkan Situs web Cozy Distro yang memungkinkan pelanggan untuk memesan produk secara online dan mengirimkannya melalui kurir. Halaman beranda website Cozy Distro menampilkan penjualan produk, termasuk produk yang sedang diobral. [4].

3. Penelitian yang dilakukan oleh Fadillah dan Fajarita menghasilkan sebuah sistem yang akan memudahkan proses pemasaran produk. Metode pembayaran yang digunakan adalah payment gateway sehingga customer dimudahkan dalam transaksi pembelian furniture di King Akor's. [5].

4. Penelitian yang dilakukan oleh Saputra dan Widjaja menghasilkan sebuah sistem yang dapat memberikan tempat kepada supplier ataupun UMKM melakukan pemasaran produknya sehingga dapat dijual secara langsung kepada konsumen secara online [6].

5. Penelitian yang dilakukan oleh Raushan Fikri Tunny dan Aji menghasilkan sebuah website Sistem informasi penjualan sehingga proses transaksi pembelian produk yang dilakukan oleh pelanggan menjadi mudah dan cepat [7].

6. Penelitian yang dilakukan oleh Braun, Schöllhammer, dan Rosenkranz menghasilkan Template yang dikembangkan untuk pengembangan model bisnis sirkular dapat membantu menciptakan bentuk melingkar baru kolaborasi yang diaktifkan oleh ekosistem digital [8].

7. Penelitian yang dilakukan oleh Roma, Natalia, Aleksandra dan Ewa menghasilkan pengembangan konsep asli model bisnis e-platform untuk wisata berlayar. Konsep yang disajikan beralasan pada modifikasi Business Model Canvas (BMC) dalam hal struktur dan operasionalisasinya [9].

8. Penelitian yang dilakukan oleh Manuel dan Josef menghasilkan penggunaan VR untuk meningkatkan Model Bisnis di lingkungan industri 5.0 yang potensial. Pelanggan memainkan peran kunci dalam setiap model bisnis dan VR memiliki potensi untuk memperkuat retensi pelanggan [10]. 
9. Penelitian yang dilakukan oleh Dela dan Humisar menghasilkan Website yang memudahkan pemilik toko/manajer penjualan untuk memilih pesanan produk yang tepat untuk pelanggannya. Di website ini, Anda bisa dengan mudah mendapatkan kode kupon promosi yang ditawarkan oleh Brassica Florist [11].

10. Penelitian yang dilakukan oleh Taruna dan Grace menghasilkan e-commerce Mr. Bro untuk memfasilitasi perdagangan sepanjang waktu untuk pelanggan yang terdistribusi sudah bisa dibayar melalui transfer antar bank, sehingga mempercepat proses pencetakan laporan. Beberapa produk yang dijual oleh dapat terindeks oleh Google dengan implementasi SEO [12].

11. Penelitian yang dilakukan oleh Maulana dan Yuliazmi menghasilkan fitur SEO dan pemasaran dari sistem e-commerce Jeys Corner tidak hanya mempromosikan penjualan produk yang lebih besar, tetapi juga memperluas area yang mempromosikan pemasaran Internet dan iklan Google [13].

12. Penelitian yang dilakukan oleh Ari dan Samsinar menghasilkan situs e-commerce toko gentleman clothing yang dapat bersaing secara online dan meningkatkan penjualan [14].

13. Penelitian yang dilakukan oleh Lazuardi dan Samsinar menghasilkan Model bisnis yang dapat membantu mewujudkan jangkauan toko yang dibangun yang sebenarnya dibentuk dengan berdagang dengan sembilan elemen blok yang ada pada BMC dan ditampilkan pada BMC yang saling berhubungan [15].

\section{METODE PENELITIAN}

\subsection{Metode Pengumpulan Data}

1. Observasi, Peneliti mengamati langsung di toko H5 untuk mengetahui permasalahan yang ada pada lokasi tersebut. Toko H5 beralamat di Jl. Perdagangan No.2 Ampera, Jayapura Utara, Kota Jayapura, Papua. Peneliti mengamati berbagai proses mulai dari jual beli, cara karyawan melayani pelanggan, pencatatan stok dan laporan penjualan, dan sistem pembayaran yang diterapkan pada Toko H5.

2. Interview, Peneliti melakukan wawancara dengan beberapa narasumber seperti Pemilik, Karyawan dan Pelanggan Toko H5 yang menghasilkan informasi sebagai berikut:

a. Proses jual beli, hingga masalah yang terjadi pada Toko H5

b. Masalah yang dihadapi karyawan dengan sistem yang masih konvensional

c. Pandangan pelanggan mengenai Toko H5, kebiasaan berbelanja pelanggan, hingga harapan pelanggan untuk Toko H5 kedepannya

3. Studi Pustaka, Peneliti menggunakan jurnal ilmiah baik internasional maupun nasional, dan juga buku yang didapatkan melalui internet maupun koleksi pribadi

\subsection{Metode Analisis}

Model bisnis (BMC) menggambarkan strategi bisnis yang berfokus pada operasi utama (key activity), mitra utama (key partners), aliran pendapatan (revenue stream), proposisi nilai (value proposition), hubungan pelanggan (customer relationship), segmen basis pelanggan (customer segments), struktur biaya (cost structure), elemen kunci dari bisnis utama (key resources), Sumber daya saluran (channels). BMC digunakan oleh startup dan organisasi bisnis untuk mendapatkan gambaran lengkap dalam menganalisis model bisnis mereka.

\subsection{Metode Perancangan}

UML (Unified Modeling Language) adalah metode desain yang digunakan dalam penelitian ini. Model UML yang digunakan adalah class diagram, use case diagram, sequence diagram, dan activity diagram. UML dinilai tepat karena menggunakan perancangan berbasis objek sehingga dapat menggambarkan alur sistem dengan jelas, spesifik dan mudah dipahami.

\subsection{Metode Pengembangan}

Prototyping adalah metode pengembangan yang digunakan dalam penelitian ini, dimana pengumpulan kebutuhan sistem adalah proses pertama, prototyping dan evaluasi pengguna sistem adalah proses selanjutnya, dan akhirnya sistem dibuat mempertimbangkan kebutuhan pengguna.

\subsection{Metode Pengujian}

Pengujian black-box adalah metode pengujian yang digunakan dalam penelitian ini. Pada black box testing berfokus pada fungsionalitas dan output system (sistem keluaran). Black box testing memperhatikan detail sistem, fungsi pada sistem, dan alur pada sistem yang dibuat.

\section{HASIL DAN ANALISIS}

\subsection{Analisis Sistem Berjalan}

Di bawah ini adalah flowmap proses jual beli yang berjalan di toko H5, seperti terlihat pada Gambar 1 . 


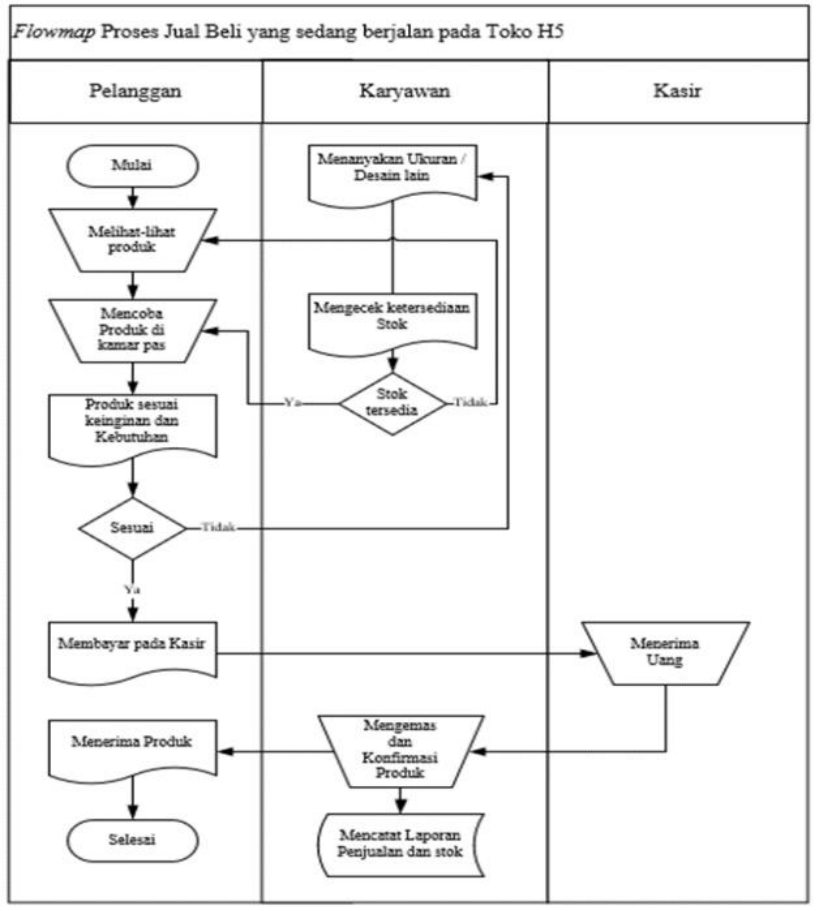

Gambar 1 Flowmap Proses Jual Beli yang berjalan

Adapun tahapan yang dilakukan dalam proses jual beli sebagai berikut:

1. Pelanggan melihat-lihat produk.

2. Pelanggan mencoba produk di kamar pas.

3. Apabila produk sesuai kebutuhan dan keinginan pelanggan maka proses berlanjut pada pembayaran di kasir.

4. Apabila produk tidak sesuai kebutuhan dan keinginan pelanggan maka pelanggan menanyakan karyawan untuk desain/ukuran yang lain.

5. Karyawan mengecek ketersediaan stok apabila tersedia maka produk tersebut diberikan kepada pelanggan untuk dicoba di kamar pas.

6. Apabila stok kosong maka karyawan akan memberitahukan kepada pelanggan dan pelanggan melihat produk serupa lainnya yang tersedia.

7. Proses selanjutnya terjadi setelah pelanggan membayar produk pada kasir yaitu kasir menerima uang dan karyawan melakukan pengemasan produk dan konfirmasi produk yang telah dibayarkan.

8. Pelanggan menerima produk dan proses terakhir adalah pencatatan laporan penjualan dan stok yang dilakukan oleh karyawan.

\subsection{Usulan Pemecahan Masalah}

\subsubsection{Current Business Model Canvas}

\section{Customer Segments}

Basis segmen pelanggan yang menjadi target Toko H5 adalah jenis segmented, secara khusus mengelompokkan pelanggan berdasarkan jenis kelamin (laki-laki dan perempuan), usia (anak-anak hingga dewasa) dan kebutuhan masing-masing pelanggan.

2. Value Propositions

Nilai yang dibawa Toko H5 tidak hanya keuntungan, tetapi kualitas, tren terbaru, layanan, dan hubungan pelanggan yang baik adalah inti dari Toko H5. Beberapa unsur yang termasuk dalam value propositions antara lain:

a. Newness

Kebaruan yang dilakukan adalah rencana untuk menambah pakaian berdasarkan trend terkini di masyarakat contohnya pakaian tie dye, dan baju bertemakan game.

b. Performance

Kinerja karyawan sudah sangat baik pada saat melayani pelanggan dengan menanyakan kebutuhan pelanggan tersebut, dan membantu menyarikan stok produk yang dibutuhkan oleh pelanggan, namun karyawan lumayan kesulitan pada saat melakukan pencatatan stok dan laporan penjualan dikarenakan masih manual pada buku, saat kondisi sedang ramai tentunya 
karyawan agak sulit mencatat laporan penjualan dan stok tersebut hingga sering terjadinya kesalahan perhitungan laporan penjualan dan stok. Kinerja produk bisa dilihat dari kualitas dan harga yang diberikan oleh Toko H5 sudah sangat bagus serta memiliki harga yang terjangkau oleh pelanggan tentunya.

c. Customization

Pelanggan dapat memberikan saran produk dengan model yang sesuai dengan keinginannya yang nantinya akan dikabari oleh pemilik apabila produk tersebut telah tersedia.

d. Getting the job done

Pelanggan Toko H5 dapat meminta beberapa model produk populer saat ini namun lebih terjangkau dari segi harga serta kualitas yang lebih baik atau kurang lebih sama sebagai ganti pemesanan dan pembuatan sendiri yang dilakukan oleh pelanggan. Pelanggan memilih menunjukkan model aslinya dan meminta produk dengan model yang sama tetapi terjangkau dari segi harga.

e. Design

Pelanggan menyukai keindahan dan branding dari desain produk toko H5. Kelas menengah lebih memilih produk karena alasan estetika.

f. Brand

Beberapa produk dijual dengan merek, dan beberapa tidak dijual dengan merek. Sebagian besar merek mapan seperti Adidas sudah dikenal sebagian pelanggan. Merek Toko H5 dikenal dengan toko pakaian yang relatif terjangkau dan berkualitas.

g. Price

Harganya berkisar antara 20.000 hingga 250.000 rupiah, dan tentunya harga yang ditawarkan oleh toko $\mathrm{H} 5$ ini relatif murah dan kualitas yang ditawarkan juga bagus.

h. Risk reduction

Pembeli terlebih dahulu diminta untuk mengecek produk sebelum membayar. Jika produk yang dibeli cacat atau rusak dalam beberapa jam setelah pembelian, toko akan menjamin produk yang dijualnya selama tidak ada yang bisa dilakukan mengenai kondisi barang tersebut. Misalnya, jika ada produk yang cacat atau rusak, toko $\mathrm{H} 5$ akan mengganti produk tersebut dengan yang baru. Jika pelanggan tidak mengatakan apa-apa, maka tidak ada masalah dengan produk. Oleh karena itu, setelah beberapa jam, jika Anda tiba-tiba melaporkan "cacat", Anda tidak dapat mengembalikannya kecuali Anda mengklaimnya pada hari yang sama.

i. Accessibility

Karena perbedaan ekonomi individu, tidak semua orang mampu membeli produk yang dijual Toko H5, dan pelanggan menganggap ini didasarkan pada persepsi harga masing-masing individu. Namun, siapa pun dapat mengakses toko ini.

j. Usability

Produk yang dijual adalah baju, celana, jaket, dress, dan lainnya yang bisa dipakai langsung, dan sangat mudah digunakan secara keseluruhan.

\section{Channels}

Tabel 1. Channels yang digunakan Toko H5

\begin{tabular}{c|c|c}
\hline \multirow{2}{*}{ Fase } & \multicolumn{2}{c}{ Jenis saluran } \\
\cline { 2 - 3 } & $\begin{array}{c}\text { Direct } \\
\text { /langsung }\end{array}$ & $\begin{array}{c}\text { Indirect/ } \\
\text { tidak langsung }\end{array}$ \\
\hline $\begin{array}{c}\text { Awareness } \\
\text { (penyampaian } \\
\text { informasi) }\end{array}$ & $\begin{array}{c}\text { Karyawan / } \\
\text { Pemilik Toko }\end{array}$ & Rekomendasi dari pihak lain di luar Toko H5 \\
$\begin{array}{c}\text { Evaluations } \\
\text { (penyampaian }\end{array}$ & & \\
informasi apabila \\
kurang jelas) \\
$\begin{array}{c}\text { Purchase } \\
\text { (pembayaran oleh } \\
\text { konsumen) } \\
\text { Delivery } \\
\text { (pengiriman ke } \\
\text { konsumen) } \\
\text { Aftersales } \\
\text { (penyampaian } \\
\text { tanggapan) }\end{array}$ & Cash On Delivery & \\
\hline & & Telepon / whatsapp \\
\hline
\end{tabular}




\section{Costumer Relationships}

Selalu berusaha untuk menjaga hubungan baik dengan pelanggannya adalah hal utama yang dilakukan Toko H5. Selain itu, jenis hubungan pelanggan yang berlaku untuk toko H5 dapat dikatakan sebagai dukungan pribadi seperti personal assistance (di mana pelanggan berinteraksi langsung dengan karyawan, dan pemilik) serta dedicated personal assistance (pelayanan secara langsung oleh pemilik Toko).

\section{Revenue Streams}

Toko H5 menghasilkan uang dari menjual produk mereka. Penetapan harga yang digunakan yakni harga tetap (fixed menu pricing), yaitu harga yang diberikan sesuai dengan kualitas. Harga tetap, tetapi Toko H5 masih menawarkan opsi untuk memungkinkan pelanggan menawar produk tersebut.

\section{Key Resources}

Sumber daya kritis yang dimiliki Toko H5 yakni physical (peralatan fisik, yaitu gedung lantai satu, rak besi, ruang loker dan CCTV), intellectual (brand and partnership), human (karyawan), dan financial (uang tunai).

\section{Key Activities}

Aktivitas kunci adalah langkah terpenting yang dibutuhkan bisnis untuk berhasil. Toko H5 tidak melakukan pekerjaan manufaktur, hanya mendistribusikan ke pelanggan. Kegiatan toko H5 adalah memesan produk dari supplier, menunggu kiriman, menerima kiriman, menyimpan, mempersiapkan penjualan, memajang dan menjual produk baru. Selain itu melakukan promosi pada produk dengan memberikan diskon khusu semisal pada hari-hari besar nasional.

\section{Key Partnerships}

Potensi yang terlihat pada sisi partner yakni dengan adanya supplier dan customer tentunya membantu pemilik dalam mencapai tujuannya. Tidak hanya itu, partner yang dimiliki sekarang dapat mempertahankan hubungan dalam jangka panjang.

\section{Cost Structure}

Penyeimbangan cost driven dan value driven yang dilakukan oleh Toko H5. 4 cost structure pada Toko H5 yaitu variable costs (barang yang dijual, buku penjualan harian dan stok ), economies of scale (pada saat tertentu di mana penjualan harian tergolong ramai, maka biaya operasional yang dikeluarkan akan cenderung menurun), fixed costs (biaya gaji karyawan, biaya peralatan untuk dekorasi toko), serta economies of scope (berbagai produk yang digabung menjadi dagangan pada 1 toko di mana hal ini menyebabkan scope lebih besar sehingga biaya yang seharusnya digunakan untuk membuka 2 toko menjadi turun).

\section{Tabel 2. Current Business Model Canvas}

\begin{tabular}{|c|c|c|c|c|}
\hline \multirow[t]{3}{*}{$\begin{array}{l}\text { Supplier } \\
\text { Pelanggan } \\
\text { rekan kerja. }\end{array}$} & $\begin{array}{ll}\text { Key Resources } \\
& \\
\text { a. } & \text { Fasilitas fisik } \\
& \vdots \\
& \text { bangunan } \\
& \text { lantai } 1, \\
\text { gantungan } & \\
& \text { besi, Kamar } \\
& \text { Pas, dan cctv } \\
\text { b. Intellectual : } & \text { merek dan } \\
& \text { partnerships } \\
\text { c. Human : } & \text { karyawan } \\
\text { d. Financial : } & \text { uang tunai. }\end{array}$ & \multirow[t]{2}{*}{$\begin{array}{l}\text { Newness, } \\
\text { performance, } \\
\text { customization, } \\
\text { getting the job } \\
\text { done, design, } \\
\text { brand, price, risk } \\
\text { reduction, } \\
\text { accessibility dan } \\
\text { usability. }\end{array}$} & $\begin{array}{l}\text { Customer Relationships } \\
\text { Personal assistance, dan } \\
\text { dedicated personal assistance }\end{array}$ & \multirow[t]{3}{*}{ Segmented market } \\
\hline & 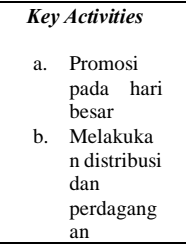 & & $\begin{array}{l}\text { Channels } \\
\text { a. Direct (channels } \\
\text { sendiri) dan indirect } \\
\text { (partner channels) } \\
\text { b. Fase channels : } \\
\text { awareness, evaluation, } \\
\text { purchase, delivery dan } \\
\text { after sales }\end{array}$ & \\
\hline & $\begin{array}{l}\text { Cost Structure } \\
\text { a. Cost driven dan } \\
\text { b. Fixed costs (bia } \\
\text { untuk dekorasi } \\
\text { dijual, buku } \\
\text { economies of sc }\end{array}$ & $\begin{array}{l}\text { wan, biaya peralatan } \\
\text { e costs (barang yang } \\
\text { harian dan stok), } \\
\text { nomies of scope. }\end{array}$ & $\begin{array}{l}\text { Revenue Streams } \\
\text { Sumber : penjualan produk }\end{array}$ & \\
\hline
\end{tabular}




\subsubsection{Future Business Model Canvas}

Berdasarkan pembahasan kerangka model bisnis toko H5 saat ini (current business model canva), peneliti ingin merekomendasikan kerangka model bisnis masa depan (future business model canvas) yang mungkin berguna untuk toko H5, antara lain:

\section{Customer Segments}

Toko H5 menciptakan e-commerce untuk mengembangkan customer segments untuk pasar yang beragam (diversied).

2. Value Propositions

Toko H5 meningkatkan proposisi nilai yang ada dengan memungkinkan pelanggan untuk merancang produk dengan sampel yang diminta sebelumnya, dan Toko H5 juga dapat membuat merek mereka sendiri.

3. Channels

Toko H5 dapat memperluas jangkauan mereka dengan Meningkatkan efisiensi kerja karyawan yang antusias menarik pelanggan untuk datang ke toko. Pendekatan tidak langsung dapat dikembangkan oleh toko H5 menggunakan e-commerce dan bekerja sama dengan layanan pengiriman seperti JNE, POS Indonesia dan J\&T untuk pengiriman produk diluar kota jayapura sehingga dapat memperluas pasar ke seluruh indonesia dan juga layanan Grab, Go-Jek, maupun jasa kurir lainnya untuk pengiriman di Kota Jayapura.

4. Customer Relationships

Berdasarkan faktor ini, Toko H5 dapat terus melanjutkan costumer relationshipsnya namun mengembangkan kategori customer relationships yang ada menjadi self service (dengan menggunakan E-Commerce).

5. Revenue Streams

Melakukan pembukaan cabang dengan memperhatikan lokasi yang strategis dan tempat penyewaan yang tergolong murah untuk menambah pemasukan Toko H5.

6. Key Resources

Sumber daya utama yang dapat dikembangkan Toko H5 antara lain penyediaan fasilitas fisik berupa mobil box, pengembangan karyawan, serta menyediakan teknologi untuk ponsel dan komputer pribadi melalui Internet, hal lain yang tak kalah pentingnya yaitu memperbaiki sistem pembayaran pada toko dengan menyediakan mesin Electronic Data Capture (EDC) sehingga pelanggan yang tidak memiliki uang cash dapat membayar menggunakan kartu ATM.

7. Key Activities

Kegiatan yang dilakukan Toko H5 meliputi pembentukan segmen pelanggan baru, rencana pengembangan konsep untuk diimplementasikan, mengadakan sesi pengarahan (briefing) seminggu sekali, dan stimulasi peningkatan karyawan (training).

8. Key Partnerships

Dari sudut pandang pelanggan, Toko H5 perlu menawarkan diskon dan kartu keanggotaan kepada pelanggan, terutama yang merupakan reseller atau grosir, untuk memberi mereka nuansa yang lebih mewah. Secara finansial, toko H5 harus terus menggunakan uang cash hasil penjualan di toko fisik.

9. Cost Structure

Cost driven dan value driven tetap menjadi fokus utama, dan juga pengurangan fixed costs dirasa perlu yaitu biaya peralatan untuk dekorasi toko yang tidak dibutuhkan. 
Tabel 3. Future Business Model Canvas

\begin{tabular}{|c|c|c|c|c|}
\hline \multirow[t]{3}{*}{$\begin{array}{l}\text { Supplier, } \\
\text { Pelanggan, dan } \\
\text { rekan kerja. }\end{array}$} & $\begin{array}{l}\text { Key Resources } \\
\text { a. Fasilitas fisik : bangunan } \\
\text { lantai 1, gantungan besi, } \\
\text { Kamar Pas, cctv, dan mobil } \\
\text { box } \\
\text { b. Intellectual : merek dan } \\
\text { partnerships } \\
\text { c. Human : karyawan } \\
\text { d. Financial : uang tunai. } \\
\text { e. Sistem pembayaran: } \\
\text { Menyediakan mesin EDC } \\
\text { f. Teknologi: Internet dan } \\
\text { Komputer }\end{array}$ & $\begin{array}{l}\text { Value Propositions } \\
\text { a.Newness, } \\
\text { performance, } \\
\text { customization, } \\
\text { getting the job } \\
\text { done, design, } \\
\text { brand, price, risk } \\
\text { reduction, } \\
\text { accessibility dan } \\
\text { usability. Design } \\
\text { b. tedah } \\
\text { produk dari model } \\
\text { yang tirelaest tol } \\
\text { direaus }\end{array}$ & $\begin{array}{l}\text { Customer Relationships } \\
\text { a. Personal } \\
\text { assistance, dan } \\
\text { dedicated personal } \\
\text { assistance } \\
\text { b. self service (dengan } \\
\text { sistem online } \\
\text { menggunakan E- } \\
\text { Commerce) }\end{array}$ & \multirow[t]{2}{*}{$\begin{array}{l}\text { Segmented market, } \\
\text { Customer segments } \\
\text { yang baru : para } \\
\text { pengguna E-Commerce }\end{array}$} \\
\hline & $\begin{array}{l}\text { Key Activities } \\
\text { a. Promosi pada hari besar } \\
\text { b. Melakukan distribusi dan } \\
\text { perdagangan } \\
\text { c. Pengembangan SDM: } \\
\text { Briefing dan Training }\end{array}$ & $\begin{array}{l}\text { c. Toko H5 dapat } \\
\text { membuat } \\
\text { brandnya sendiri }\end{array}$ & $\begin{array}{l}\text { Channels } \\
\text { a. Direct (channels } \\
\text { sendiri) dan indirect } \\
\text { (partner channels) } \\
\text { b. Fase channels } \\
\text { awareness, } \\
\text { evaluation, purchase, } \\
\text { delivery dan after } \\
\text { sales } \\
\text { c. Jasa Pengiriman } \\
\text { dalam dan luar kota: } \\
\text { JNE, POS Indonesia, } \\
\text { J\&T Grab serta Gojek }\end{array}$ & \\
\hline & \multicolumn{2}{|c|}{$\begin{array}{l}\text { Cost Structure } \\
\text { a. Cost driven dan value driven } \\
\text { b. Fixed costs (biaya gaji karyawan, biaya peralatan untuk } \\
\text { dekorasi toko), variable costs (barang yang dijual, buku } \\
\text { penjualan harian dan stok), economies of scale serta } \\
\text { economies of scope. }\end{array}$} & \multicolumn{2}{|c|}{$\begin{array}{l}\text { Revenue Streams } \\
\text { a. Sumber : penjualan produk } \\
\text { b. pembukaan cabang dari Toko H5 }\end{array}$} \\
\hline
\end{tabular}

\subsubsection{Analisis Kebutuhan Fungsional}

E-commerce ini digunakan oleh tiga jenis pengguna: pelanggan, admin, dan pemilik toko. Ecommerce didasarkan pada asumsi bahwa pengguna terbiasa menggunakan sistem berbasis web. Pengguna yang di asumsikan adalah sebagai berikut:

\section{Admin.}

, termasuk tampilan dasbor, manajemen data katalog, manajemen data transaksi offline, manajemen data transaksi online, manajemen data keuangan, manajemen data pemasaran, manajemen data pengguna, manajemen data mitra, manajemen desain situs web Toko H5, manajemen data pesan dan kontak, manajemen data costumer service, manajemen data widget, manajemen data news/blog, manajemen halaman data, manajemen data, sistem penempatan kode, tampilan dokumen. melihat dashboard, mengelola katalog, mengelola transaksi offline, mengelola pembelian online, manajemen keuangan, manajemen marketing, manajemen user, manajemen partner, mengelola design website toko h5, mengelola data kontak dan pesan, mengelola data customer service, manajemen widget, manajemen news/blog, manajemen informasi pages, manajemen system, setting cod, melihat dokumentasi sistem.

\section{Pelanggan.}

Melakukan registrasi, mendapat informasi Toko H5, mendapat diskon dan voucher, cek resi, konfirmasi pembayaran, memberikan ulasan produk, retur produk, melakukan pembelian, menjadi member/reseller.

\section{Pemilik.}

Melihat dashboard, dan memantau proses penjualan yang dilakukan admin.

\subsubsection{Analisis Kebutuhan Non Fungsional}

Persyaratan non-fungsional meliputi: :

1. Perangkat lunak yang di gunakan
a. Windows 10 Home Single Language
b. Adobe Dreamweaver 2020
c. Microsoft Visio 2019
d. Browser Microsoft Edge atau Google Chrome
e. Xampp
f. Hosting dan Domain Website

2. Perangkat keras yang di gunakan
a. Laptop ACER
b. RAM $8 \mathrm{~GB}$ 
c. Hardisk 1 TB

d. Printer Epson L360

3. User meliputi admin, pemilik, dan pelanggan

4. Jaringan Internet

5. Basis data dan sistem aplikasi yang aman dengan kata password

6. Aplikasi yang mudah digunakan

\subsection{Perancangan Sistem}

Perancangan sistem yang memberikan definisi bentuk dan proses perangkat lunak akan dilakukan sehingga hasil analisis yang ditetapkan dalam perancangan program akan selesai.

\subsubsection{Use case Diagram}

use case dalam penelitian ini, meliputi use case pelanggan, use case admin dan pemilik toko.

\section{Use case Pelanggan}

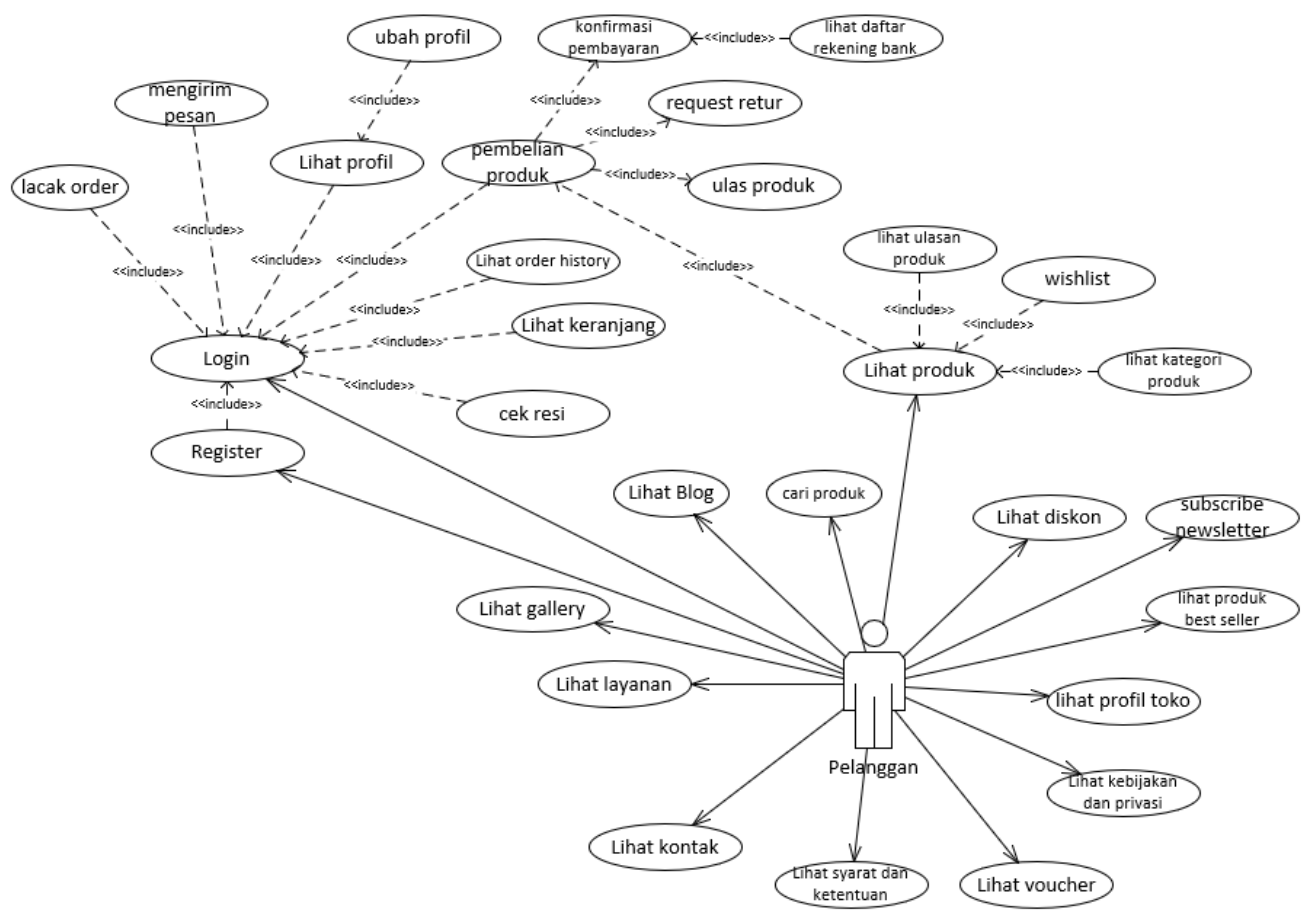

Gambar 2 Use case Pelanggan

Berdasarkan Gambar 2 menjelaskan use case pelanggan, Hak akses dari pelanggan pada $E$ Commerce ini yaitu Aktor pelanggan dapat melakukan aktivitas lihat produk, lihat ulasan produk, lihat kategori produk, lihat diskon, subscribe newsletter, lihat produk best seller, lihat profil toko, lihat kebijakan dan privasi, lihat voucher, lihat syarat dan ketentuan, lihat kontak, lihat layanan, lihat gallery, lihat blog, dan cari produk. Untuk aktivitas lainnya pelanggan diharuskan melakukan login terlebih dahulu apabila sudah mempunyai akun, jika belum pelanggan dapat melakukan registrasi terlebih dahulu. Setelah melakukan login pelanggan dapat melakukan aktivitas lacak order, mengirim pesan, lihat profil, ubah profil, pembelian produk, konfirmasi pembayaran, lihat daftar rekening bank, request retur, ulas produk, lihat order history, lihat keranjang, dan cek resi. Fungsi utama dari aktor Pelanggan pada E-Commerce ini yaitu melakukan pembelian produk. 


\section{Use case Admin dan Pemilik Toko}

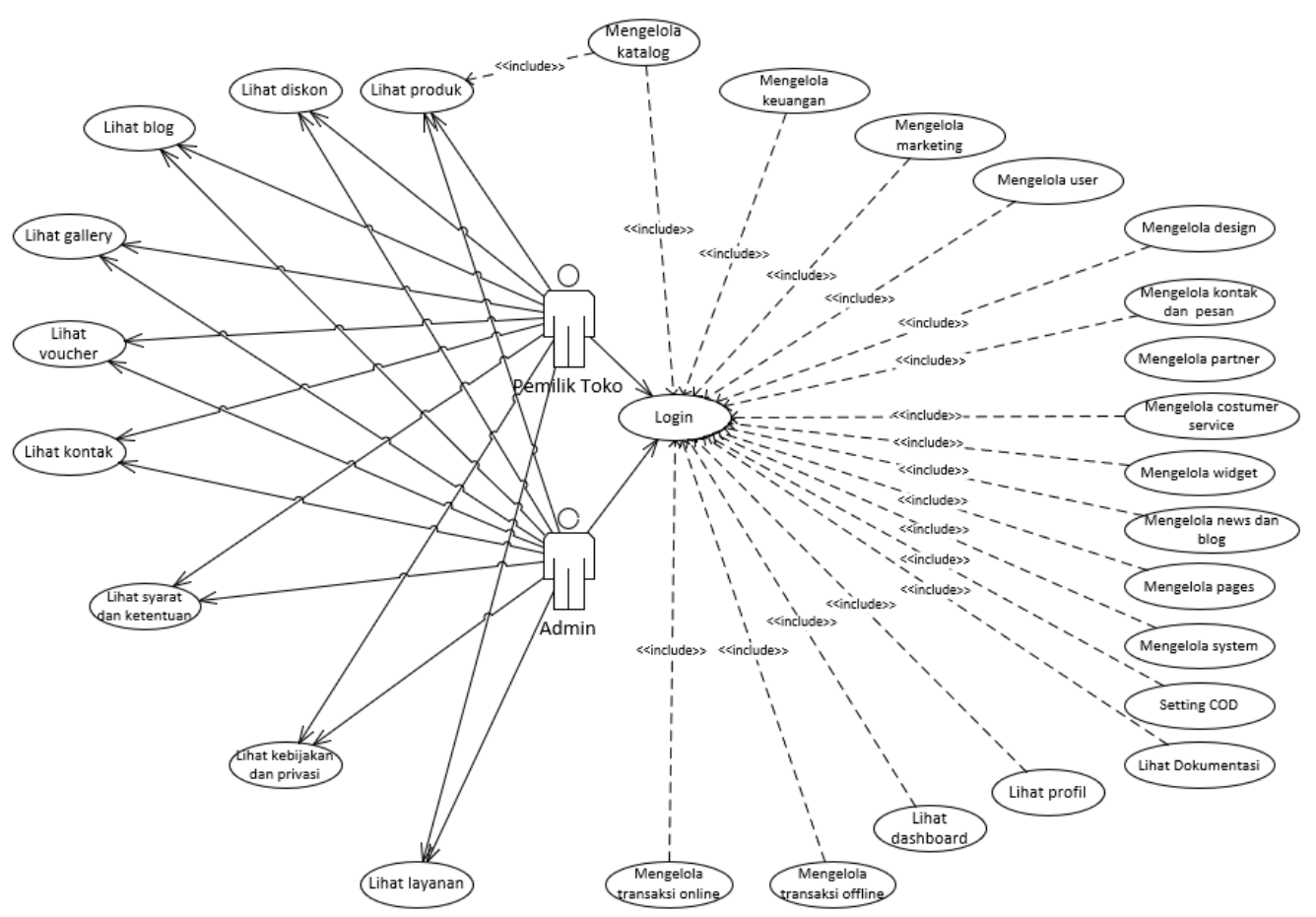

Gambar 3 Use case Admin dan Pemilik Toko

Gambar 3 menjabarkan use case admin dan pemilik toko, Hak akses dari admin dan pemilik toko pada E-Commerce ini yaitu Aktor admin dan pemilik toko dapat melakukan aktivitas lihat produk, lihat diskon, lihat blog, lihat gallery, lihat voucher, lihat kontak, lihat kebijakan dan privasi, lihat syarat dan ketentuan, lihat layanan. Untuk aktivitas lainnya admin dan pemilik toko diharuskan melakukan login terlebih dahulu, Setelah melakukan login admin dan pemilik toko dapat melakukan aktivitas mengelola katalog, mengelola keuangan, mengelola marketing, mengelola user, mengelola design, mengelola kontak dan pesan, mengelola partner, mengelola costumer service, mengelola widget, mengelola news dan blog, mengelola pages, mengelola system, Setting COD, lihat dokumentasi, lihat profil, lihat dashboard, mengelola transaksi offline, dan mengelola transaksi online. Fungsi dari aktor admin pada E-Commerce ini yaitu melakukan pengelolaan data yang sudah tersebut diatas, sedangkan untuk pemilik toko lebih melakukan pengawasan terhadap penjualan dan data yang dikelola admin pada E-Commerce ini.

\subsection{Desain Antarmuka}

Desain antarmuka penerapan Business Model Canvas pada E-Commerce Toko H5 Jayapura, sebagai berikut: 
JSAI : Journal Scientific and Applied Informatics

Vol. 4, No. 2, Bulan Tahun, hal. 204 220

E-ISSN: 2614-3054; P-ISSN: 2614-3062, accredited by Kemenristekdikti, Sinta 5

DOI: 10.36085

\subsubsection{Desain Halaman Beranda}

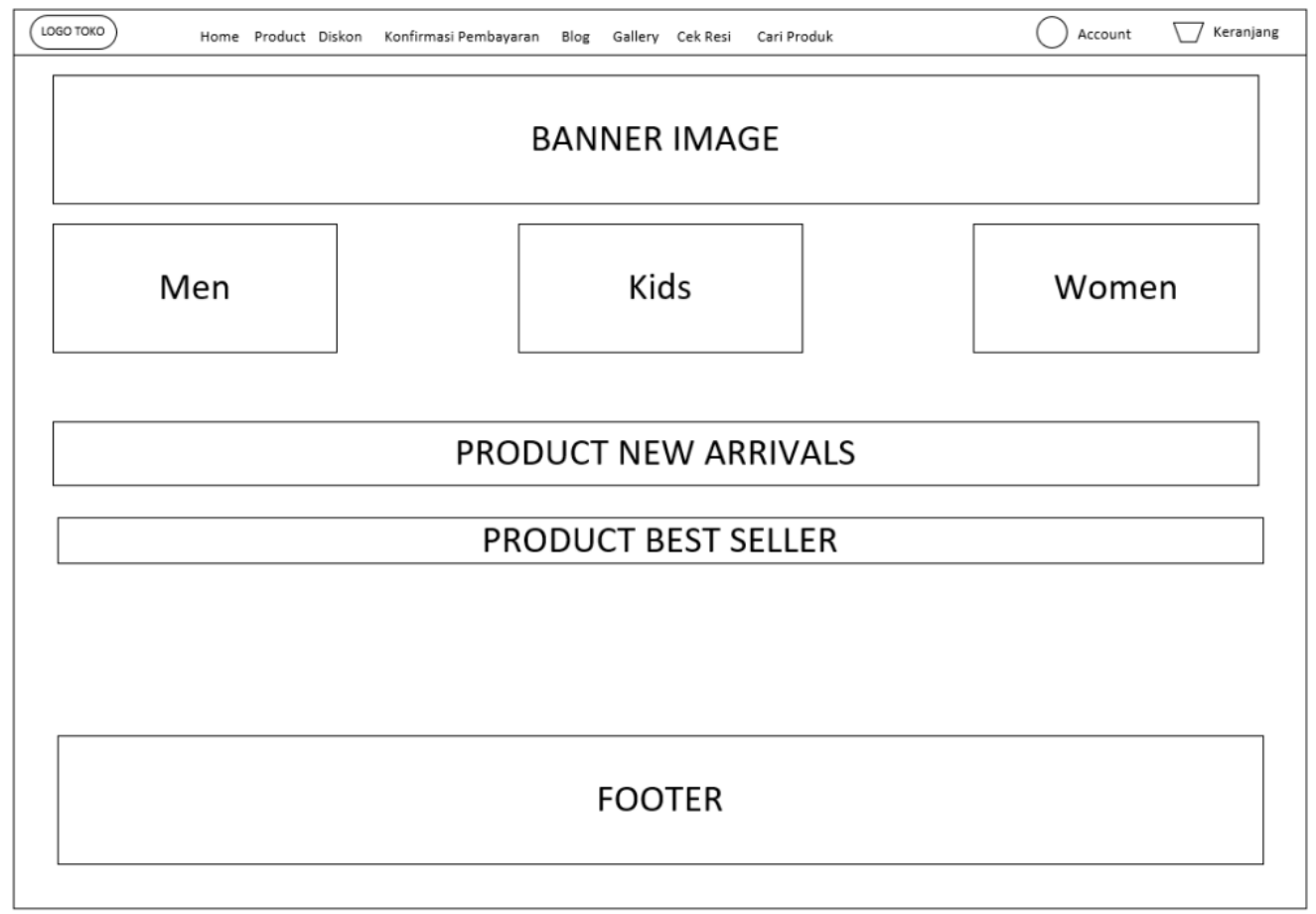

Gambar 4 Desain Halaman Beranda

Berdasarkan Gambar 4, halaman ini akan pertama kali ditampilkan saat anda mengunjungi website ECommerce Toko H5 Jayapura.

\subsubsection{Desain Halaman Dashboard}

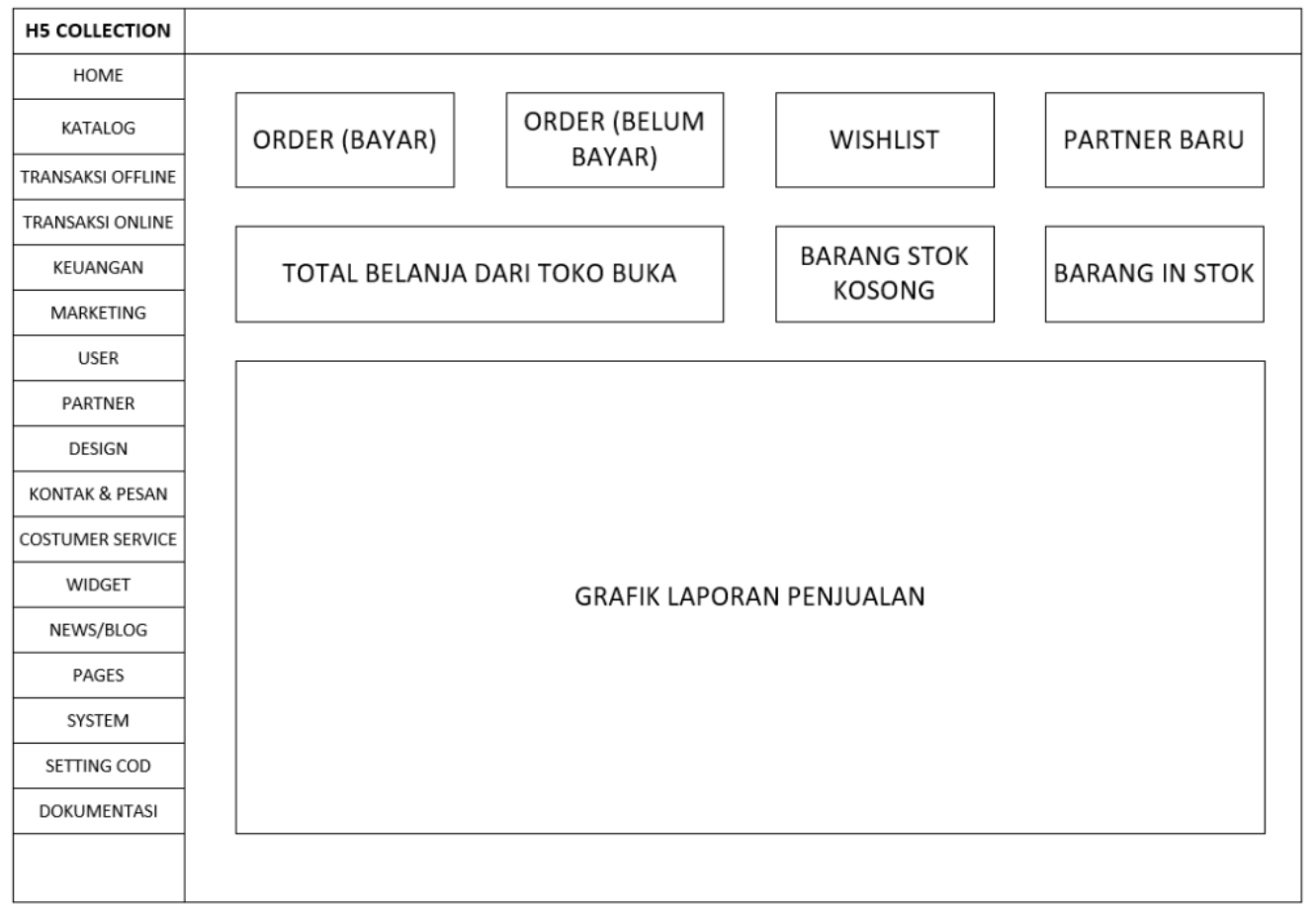

Gambar 5 Desain Halaman Dashboard

Sesuai Gambar 5, setelah berhasil login oleh admin/pemilik toko maka akan muncul halaman dashboard. 


\subsection{Implementasi Antarmuka}

Implementasi antarmuka penerapan Business Model Canvas pada E-Commerce Toko H5 Jayapura, sebagai berikut:

\subsubsection{Halaman Beranda}

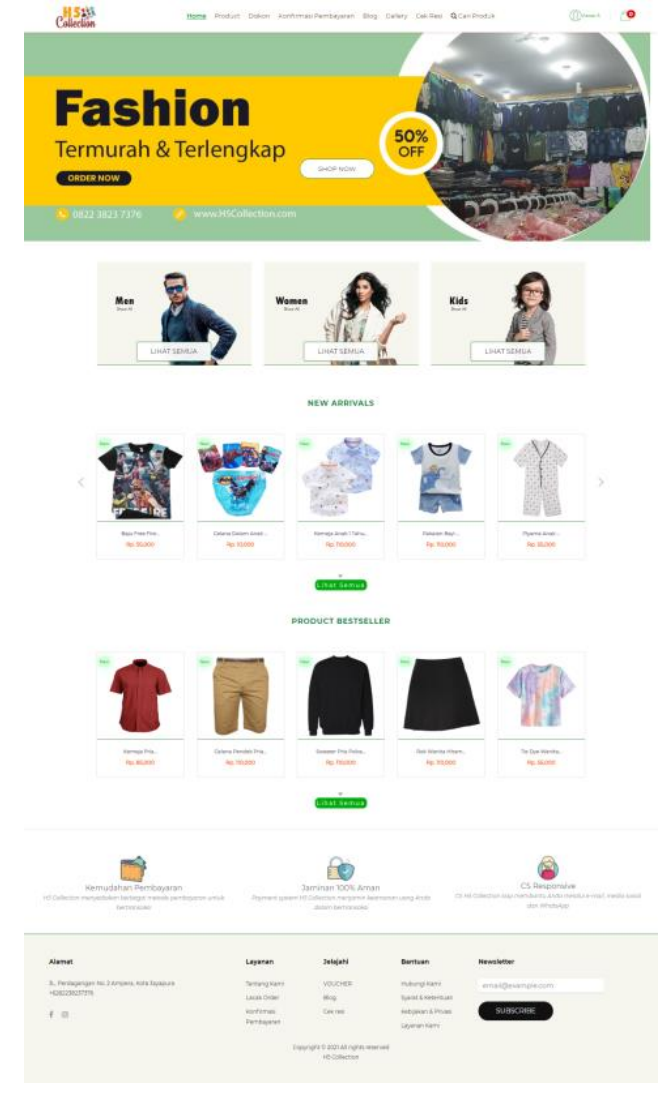

Gambar 6 Halaman Beranda

Berdasarkan Gambar 6, halaman ini muncul pertama kali saat mengunjungi situs E-Commerce Toko H5 Jayapura. dan akan menampilkan banner image, kategori pakaian, product new arrivals, product best seller, dan footer. Di halaman ini terdapat beberapa menu, yaitu home, product, diskon, konfirmasi pembayaran, blog, gallery, cek resi, cari produk, lihat profil dan lihat keranjang pada header, dan menu alamat, layanan, jelajahi, bantuan, dan newsletter pada footer. 
JSAI : Journal Scientific and Applied Informatics

Vol. 4, No. 2, Bulan Tahun, hal. 204 220

E-ISSN: 2614-3054; P-ISSN: 2614-3062, accredited by Kemenristekdikti, Sinta 5

DOI: 10.36085

\subsubsection{Halaman Dashboard}
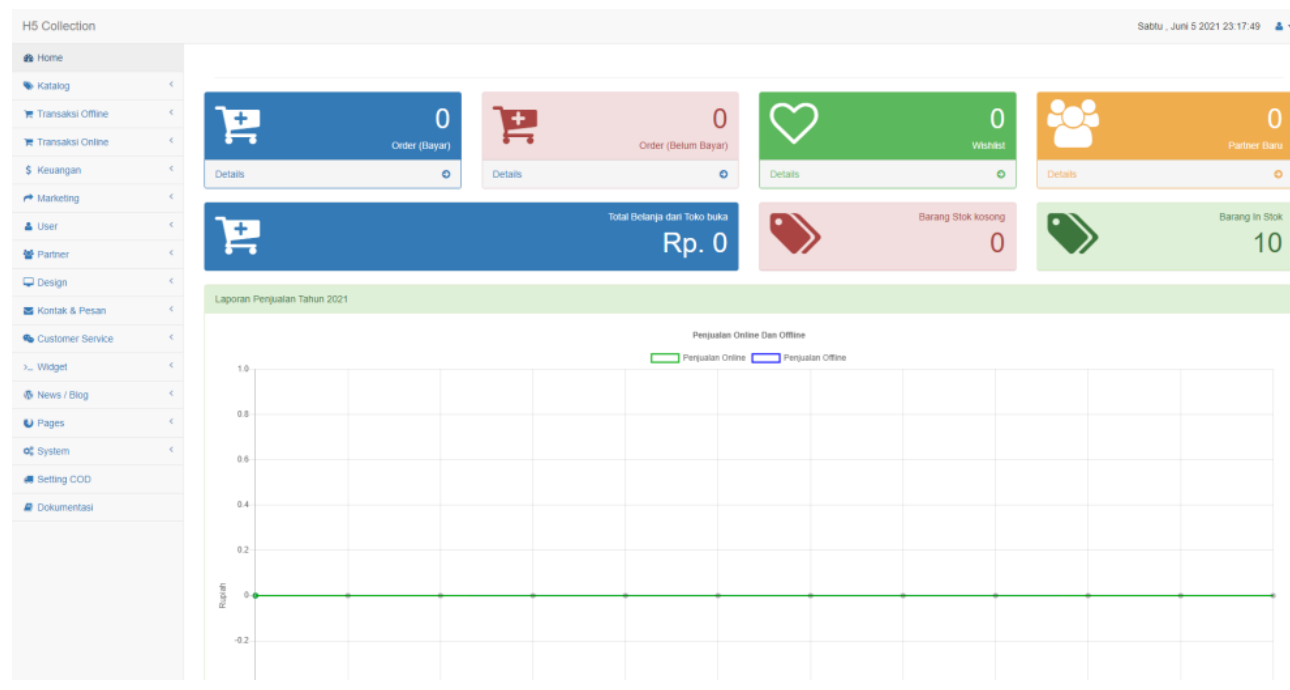

Gambar 7 Halaman Dashboard

Berdasarkan Gambar 7 menjelaskan halaman dashboard ditampilkan ketika admin/pemilik toko berhasil login. Di halaman ini terdapat beberapa menu, yaitu home, katalog, transaksi offline, transaksi online, keuangan, marketing, user, partner, design, kontak \& pesan, costumer service, widget, news/blog, pages, system, setting COD, dan dokumentasi.

\subsection{Hasil Penerapan}

Hasil Penerapan Business Model Canvas pada E-Commerce Toko H5 Jayapura, sebagai berikut:

\subsubsection{Omset}

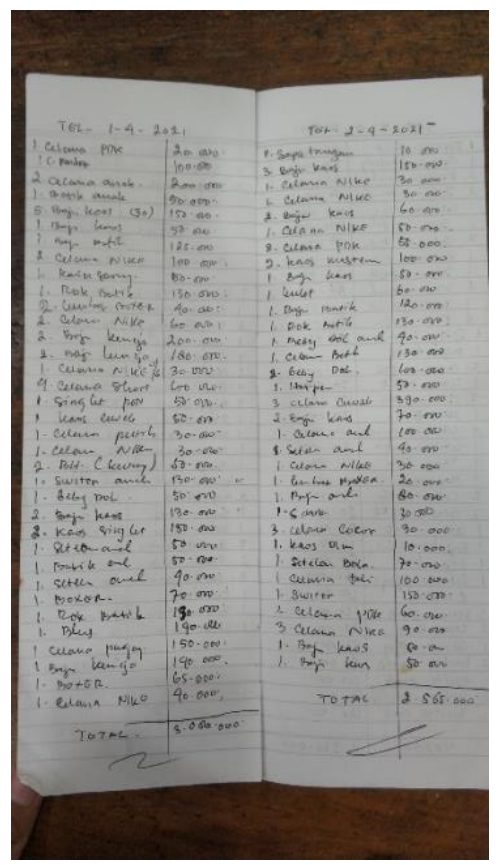

Gambar 8 Omset Penjualan sistem konvensional pada masa pandemi

Berdasarkan Gambar 8 menjelaskan laporan penjualan harian pada Toko H5 di masa pandemi yang rata-rata pendapatannya perhari mencapai 2-3 juta rupiah. 


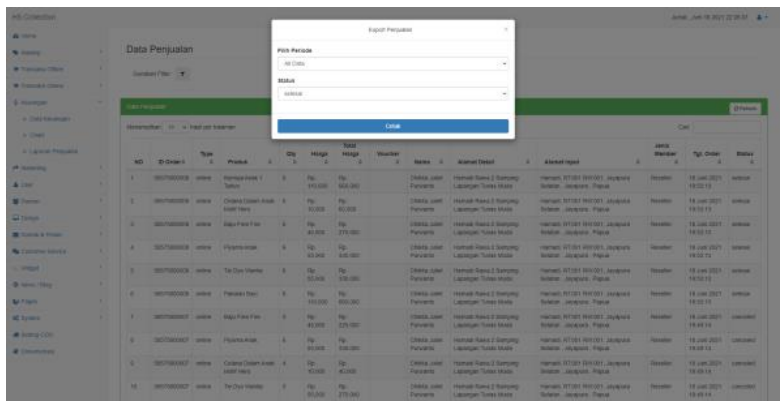

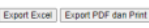

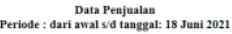

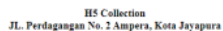

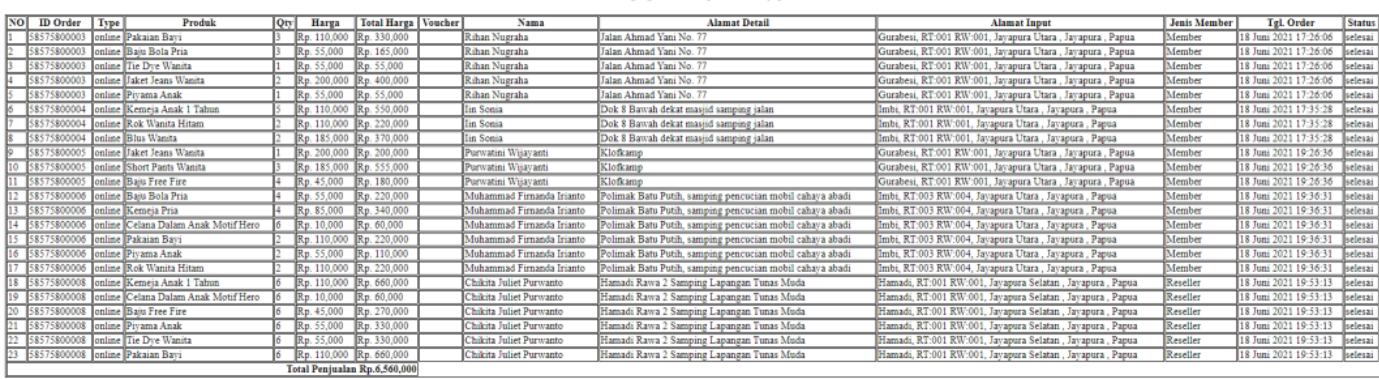

Gambar 9 Omset Penjualan pada masa pandemi menggunakan E-Commerce Toko H5

Berdasarkan Gambar 9 menjelaskan laporan penjualan harian E-Commerce pada Toko H5 di masa pandemi yang rata-rata pendapatannya perhari mencapai 6 juta rupiah.

Berdasarkan kedua perbandingan diatas dapat disimpulkan bahwa adanya E-Commerce ini dapat membantu Toko H5 meningkatkan omset penjualannya yang sebelumnya perhari hanya 2-3 juta rupiah naik menjadi 100-200\% pada angka 6 juta rupiah.

\subsubsection{Pengelolaan Laporan}

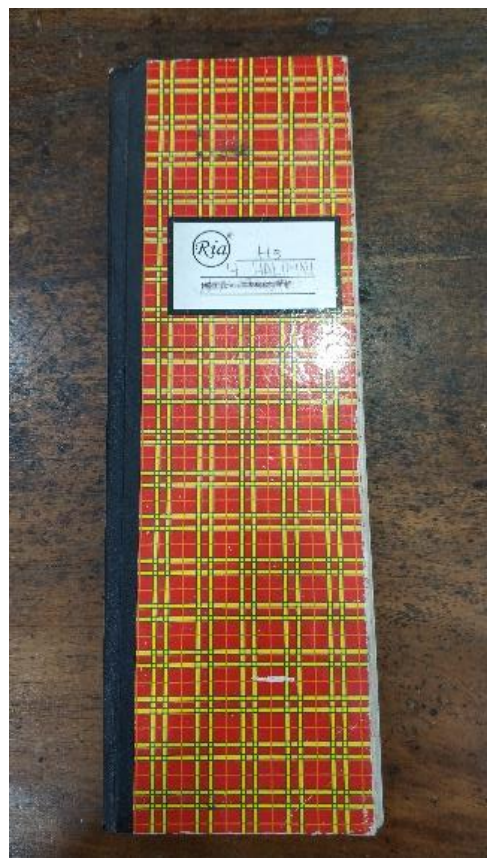

Gambar 10 Pengelolaan laporan pada sistem konvensional

Berdasarkan Gambar 10 menjelaskan pengelolaan laporan mulai dari stok barang hingga penjualan pada Toko H5 yang dicatat pada buku, pemilik juga harus menunggu hasil rekapan data dari karyawan untuk mendapatkan laporan penjualan yang valid tiap harinya sehingga hal ini kurang efisien dari segi waktu dan tenaga. 

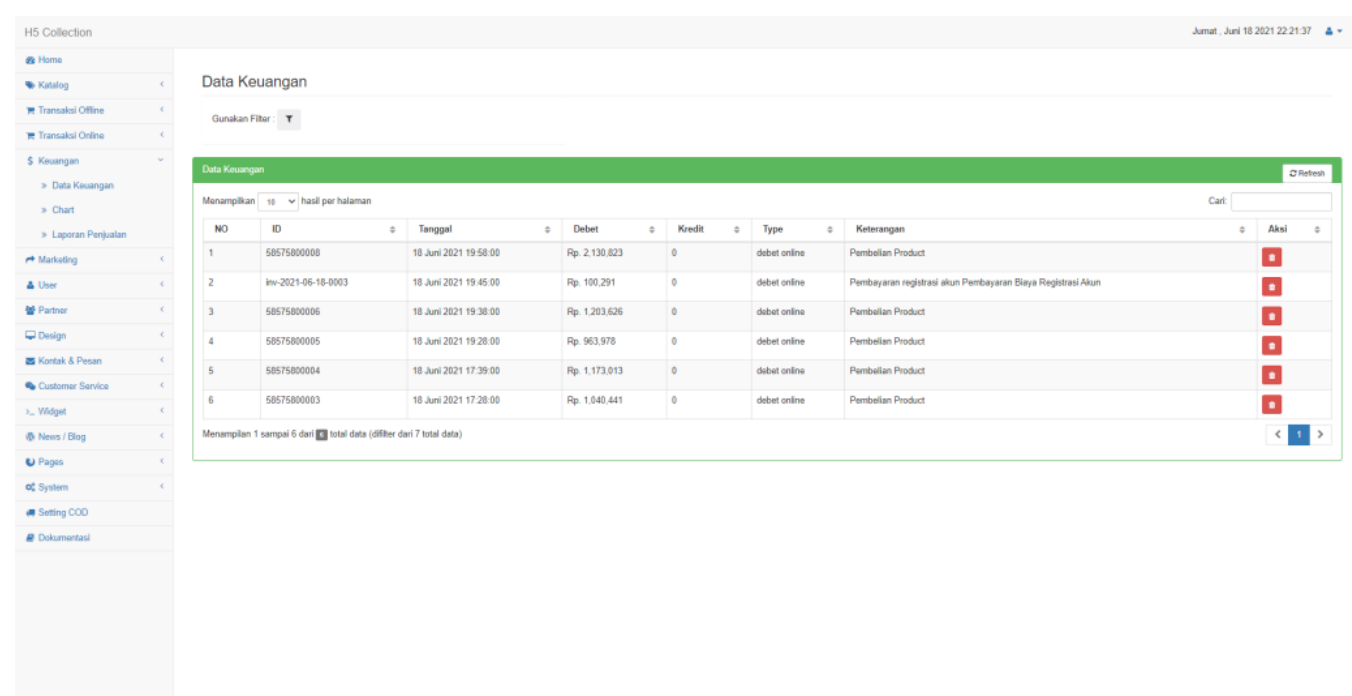

Gambar 11 Pengelolaan laporan pada E-Commerce Toko H5

Berdasarkan Gambar 11 menjelaskan pengelolaan laporan dapat dipantau langsung oleh pemilik toko mulai dari laporan data keuangan, laporan penjualan, hingga chart yang menampilkan grafik penjualan perharinya.

Berdasarkan kedua perbandingan diatas dapat disimpulkan bahwa adanya E-Commerce ini dapat memudahkan pemilik Toko dalam mengelola Toko H5 berdasarkan laporan yang ada tersebut nantinya akan digunakan untuk dasar pengambilan keputusan kedepannya mulai dari melakukan stok barang, dan pemasaran produk contohnya.

\subsubsection{Kinerja Karyawan}

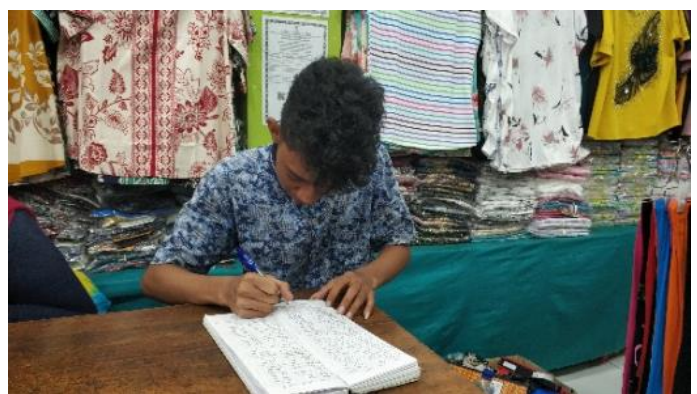

Gambar 12 Karyawan melakukan pencatatan stok dan laporan penjualan

Berdasarkan Gambar 12 menjelaskan pencatatan stok dan laporan penjualan yang dilakukan oleh karyawan pada buku hal ini terbukti kurang efisien dari segi waktu dan tenaga, apabila pencatatan barang hingga mencapai ratusan tentunya karyawan akan kelelahan melakukan pencatatan tersebut.

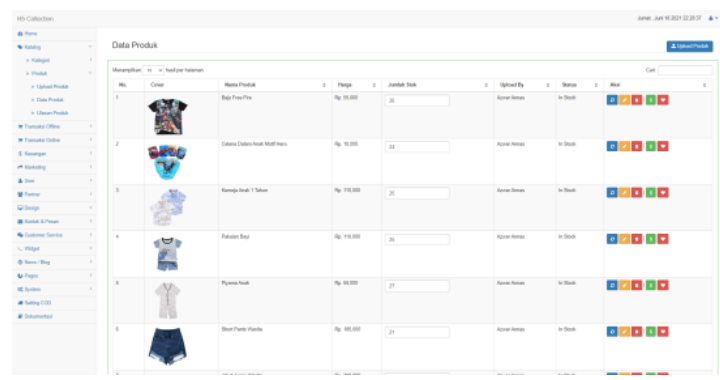

Gambar 13 Pencatatan stok dan laporan penjualan pada E-Commerce Toko H5

Berdasarkan Gambar 13 menjelaskan pencatatan stok barang dan laporan penjualan yang dapat dilakukan pada E-Commerce ini memudahkan karyawan, mulai dari memasukkan, pencarian, hingga pengelolaan data produk dan penjualan Toko H5. 
Berdasarkan kedua perbandingan diatas dapat disimpulkan bahwa adanya E-Commerce ini dapat memudahkan dan mengoptimalkan kerja dari karyawan dalam melakukan pendataan ketersediaan stok barang dan juga pencatatan laporan penjualan.

\subsubsection{Kemudahan Pelanggan}

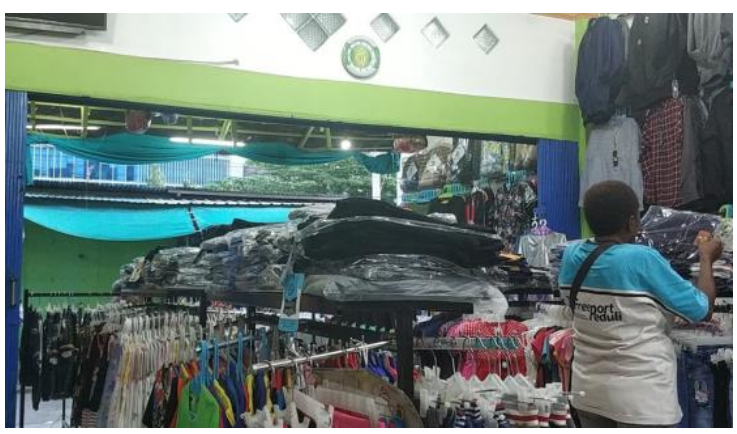

Gambar 14 Pelanggan berbelanja langsung pada Toko H5

Berdasarkan Gambar 14 menjelaskan pelanggan yang berbelanja langsung pada Toko H5, mulai dari melihat-lihat produk, hingga pembayaran dilakukan secara langsung pada toko yang tentunya tidak efisien dari segi waktu dan tenaga.

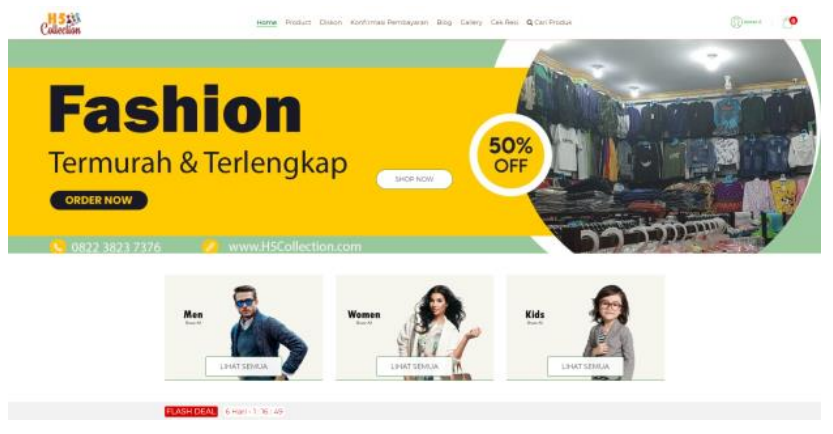

Gambar 15 Pelanggan berbelanja pada E-Commerce Toko H5

Berdasarkan Gambar 15 menjelaskan pelanggan yang dapat berbelanja pada E-Commerce Toko H5, tinggal masukan link website pada browser pelanggan dapat melakukan berbagai aktivitas mulai dari melihat-lihat produk, hingga pembayaran yang dapat dilakukan secara online.

Berdasarkan kedua perbandingan diatas dapat disimpulkan bahwa adanya E-Commerce ini dapat memudahkan pelanggan untuk berbelanja pada Toko H5 melalui E-Commerce, hal ini tentunya dapat menjaga pelanggan dari segi keamanan mengingat pada masa pandemi seperti saat ini sangat dianjurkan untuk tetap dirumah saja dan menjaga protokol kesehatan.

\section{KESIMPULAN}

Dalam pembuatan e-commerce pada toko $\mathrm{H} 5$ pada penelitian ini menghasilkan kesimpulan bahwa e-commerce yang dibuat dapat membantu meningkatkan omset pada Toko H5 Jayapura mencapai $100-200 \%$ perharinya. Selain itu Pemilik toko menjadi mudah dalam mengelola Toko H5 berdasarkan laporan yang ada sebagai dasar pengambilan keputusan kedepannya.

Dengan adanya E-Commerce ini memudahkan dan mengoptimalkan kerja dari karyawan dalam melakukan pendataan ketersediaan stok barang, serta laporan penjualan, dan yang paling penting tentunya memudahkan pelanggan untuk berbelanja pada Toko $\mathrm{H} 5$ melalui E-commerce.

\section{REFERENSI}

[1] Dwi Yuli Prasetyo, "Website e-Commerce Penjualan Sepatu Sekolah Studi Kasus : Toko Sepatu Nadin di Tembilahan," JUTI-UNISI (Jurnal Tenik Ind. UNISI), vol. 4, no. 1, p. 10, 2020.

[2] A. I. Putra and A. Diana, "Perancangan E-Commerce dengan Business Model Canvas untuk Peningkatan Penjualan pada Toko Parfum," Telematika, vol. 15, no. 1, pp. 19-28, 2020. 
[3] A. R. Fadillah and L. Fajarita, "Perancangan dan pembangunan aplikasi e-commerce berbasis web untuk meningkatkan penjualan pada toko jaket kulit naufal," J u r n a l I D E A L I S, vol. 3, pp. 8591, 2020.

[4] A. D. Saputra and A. Widjaja, "Implementasi Sistem Penjualan Online Berbasis E-Commerce Menggunakan Business Model Canvas Pada Cosy Distro," J. IDEALIS, vol. 2, no. 5, pp. 9-15, 2019.

[5] H. Setiani and A. P. Wibowo, "RANCANG BANGUN WEBSITE E-COMMERCE PADA TOKO FUNITURE (Studi Kasus : King Akor's Sragen),” p. 12, 2020.

[6] S. Widiani, T. H. Pudjiantoro, and A. I. Hadiana, "PEMBANGUNAN MEDIA E-COMMERCE FAJAR TOSERBA TALAGA," in Prosiding SNST ke-8 Tahun 2017, 2017, pp. 17-22.

[7] Raushan Fikri Tunny and A. S. Aji, "NASKAH PUBLIKASI PERANCANGAN APLIKASI ECOMMERCE PENJUALAN MENGGUNAKAN PAYMENT GATEWAY (Studi kasus: M22 Celluler Yogyakarta)," p. 12, 2020.

[8] A.-T. Braun, O. Schöllhammer, and B. Rosenkranz, "Adaptation of the business model canvas template to develop business models for the circular economy," Procedia CIRP, vol. 99, pp. 698-702, 2021, doi: 10.1016/j.procir.2021.03.093.

[9] R. Strulak-Wójcikiewicz, N. Wagner, A. Lapko, and E. Hacia, "Applying the business model canvas to design the E-platform for sailing tourism," Procedia Comput. Sci., vol. 176, pp. 1643-1651, 2020, doi: 10.1016/j.procs.2020.09.188.

[10] M. Brunner and J. Wolfartsberger, "Virtual reality enriched business model canvas building blocks for enhancing customer retention," Procedia Manuf., vol. 42, no. 2019, pp. 154-157, 2020, doi: 10.1016/j.promfg.2020.02.062.

[11] D. Renca and H. Hasugian, "Pembuatan Website Berbasis E-Commerce Menggunakan Business Model Canvas Pada Toko Brassica Florist," IDEALIS Indones. J. ..., pp. 258-264, 2019, [Online]. Available: http://jom.fti.budiluhur.ac.id/index.php/IDEALIS/article/view/2712.

[12] T. dwi Alperdo and G. Gata, "Implementasi E-Commerce Menggunakan Business Model Canvas Dan Ifml Pada Distro Mr Bro," J u r n a l I D E A L I S, vol. 2, no. 6, pp. 369-376, 2019.

[13] M. R. Haiqal and Y. Yuliazmi, "Perancangan E-Commerce Pada Jeys Corner Untuk Meningkatkan Penjualan Menggunakan Metode Business Model Canvas," IDEALIS Indones. J. ..., vol. 3, no. 2, pp. 9-14, 2020, [Online]. Available: http://jom.fti.budiluhur.ac.id/index.php/IDEALIS/article/view/2725.

[14] A. P. Pratama and S. Samsinar, "Penerapan E-Commerce Pada Toko Gentleman Clothing Menggunakan Business Model Canvas Guna Meningkatkan Penjualan ...," IDEALIS Indones. J. ..., pp. 69-76, 2019, [Online]. http://jom.fti.budiluhur.ac.id/index.php/IDEALIS/article/view/2575.

[15] L. A. Saputra and S. Samsinar, "Penerapan Business Model Canvas Dalam Membangun Web Commerce (Studi Kasus Toko Pusatsneakers_Jkt)," INOVTEK Polbeng - Seri Inform., vol. 5, no. 1, p. 46, 2020, doi: 10.35314/isi.v5i1.1320. 